\title{
Long-Term Effects of School-Based Oral Health Program on Oral Health Knowledge and Practices and Oral Health-Related Quality of Life
}

\author{
Aishah Alsumait ${ }^{a, b} \quad$ Mohamed ElSalhy ${ }^{a}$ Maryam Amin ${ }^{a}$ \\ a Department of Dentistry, Faculty of Medicine and Dentistry, University of Alberta, Edmonton, Alta., Canada; \\ ${ }^{b}$ National School Oral Health Program, Ministry of Health, Salmiya, Kuwait
}

\section{Key Words}

School health - Community dentistry · Oral hygiene .

Oral health · Dental education · Quality of life

\begin{abstract}
Objective: To evaluate the effects of exposure to the School Oral Health Program (SOHP) during primary school years on the current oral health $(\mathrm{OH})$ knowledge and practices and $\mathrm{OH}$-related quality of life (OHRQoL) of Kuwait University students. Subjects and Methods: 300 university students, aged 17.6-24.3 years, completed a validated questionnaire that consisted of 5 sections about demographics, health selfevaluation, $\mathrm{OH}$ knowledge and practices and OHRQoL. Of these students, 260 were female, 40 male, 262 single and 38 married. 189 participants had attended the SOHP, while 111 had not. Frequencies and means were used for data description. The Student $t$ test was used to compare the means, while $X^{2}$ analysis was used for the associations between SOHP and non-SOHP attendance. The odds ratios (ORs) were calculated for significant factors. Results: The SOHP attendees were twice as aware of the relationship between gum problems and heart diseases than the non-SOHP $(\mathrm{OR}=2$, $95 \% \mathrm{Cl}=1.15-3.48, \mathrm{p}=0.013)$. The daily activities of the nonSOHP attendees were twice as likely to be affected by dental health issues compared to those of the SOHP attendees $(\mathrm{OR}=2.28,95 \% \mathrm{Cl}=1.41-3.68, \mathrm{p}<0.001)$. In addition, the SOHP attendees were 3 times as likely to describe their $\mathrm{OH}$
\end{abstract}

\begin{tabular}{ll}
\hline KARGER 125/s & $\begin{array}{l}\text { ( } 2015 \text { S. Karger AG, Basel } \\
1011-7571 / 15 / 0244-0362 \$ 39.50 / 0\end{array}$ \\
$\begin{array}{l}\text { E-Mail karger@karger.com } \\
\text { www.karger.com/mpp }\end{array}$ & $\begin{array}{l}\text { This is an Open Access article licensed under the terms of the } \\
\text { Creative Commons Attribution-NonCommercial 3.0 Un- } \\
\text { ported license (CC BY-NC) (www.karger.com/OA-license), } \\
\text { applicable to the online version of the article only. Distribu- } \\
\text { tion permitted for non-commercial purposes only. }\end{array}$
\end{tabular}

status as good/very good/excellent than the non-SOHP attendees $(\mathrm{OR}=2.85,95 \% \mathrm{Cl}=1.31-6.18, \mathrm{p}=0.008)$. Conclusions: The SOHP attendees had a better OHRQoL and overall self-satisfaction with their $\mathrm{OH}$ than the non-SOHP attendees with insignificant differences between the 2 groups in $\mathrm{OH}$ knowledge and practices.

(c) 2015 S. Karger AG, Basel

\section{Introduction}

Worldwide, oral disease is a major health burden among high-, middle- and low-income populations [1]. Oral health $(\mathrm{OH})$ is a description of the standard of health of oral and oral-related tissues that enables an individual to eat, speak and socialize without active disease, discomfort or embarrassment, and it contributes to the general well-being [2,3]. Measures of the $\mathrm{OH}$-related quality of life (OHRQoL) provide essential information when assessing treatment needs, making clinical decisions and evaluating interventions, services and programs [4-7]. School-based $\mathrm{OH}$ programs were established to overcome the barriers that children and families faced in accessing dental services and to remove inequalities in $\mathrm{OH}$ between children in different communities [8-10]. The main aim of community- and school-based $\mathrm{OH}$ programs is to improve the OHRQoL of children through $\mathrm{OH}$ education, prevention and treatment strategies $[3,8,11]$. Yet, 
the effect of these programs on $\mathrm{OH}$ knowledge and practices and OHRQoL after the children leave the schools has not been investigated.

The School Oral Health Program (SOHP) in Kuwait was established in 1983 to provide dental education, prevention and treatment for children between the ages of 6 and 14 years [12], which is consistent with the WHO recommendations about integrating $\mathrm{OH}$ services into primary schooling systems $[13,14]$. These services are offered both through mobile and fixed clinics at the schools. The program provides preventive and treatment procedures for approximately 300,000 schoolchildren, and approximately $60-70 \%$ of them received preventive or therapeutic treatment in 2004 [15]. This represents nearly double the number of the targeted schoolchildren who were treated in 1992 [15]. The effectiveness of the project was evaluated through 4 national $\mathrm{OH}$ surveys conducted by the SOHP in 1982, 1985, 1993 and 2001 that determined the $\mathrm{OH}$ status of children based on biological measures of the children's $\mathrm{OH}$ [12].

Program evaluation is the process of assessing a program's short- and long-term impacts. Historically, $\mathrm{OH}$ researchers tended to focus mainly on the biological etiology of dental decay [2]. In recent years, however, more emphasis has been placed on other $\mathrm{OH}$ determinants such as $\mathrm{OH}$ knowledge and the impact of $\mathrm{OH}$ on the quality of life [16]. Most published reports on $\mathrm{OH}$ have evaluated either short clinical or health education interventions [8, 13]; however, Cooper et al. [17] advocated for the need to utilize psychosocial theories for a better and more efficient assessment of school-based $\mathrm{OH}$ programs [17].

Almost all studies that evaluated the impact of the school-based programs evaluated the effects on children during their involvement in the program, and no studies evaluated the long-term impact of the SOHP on students several years after schooling $[8,17,18]$. Hence, there is a need to evaluate the $\mathrm{OH}$ knowledge and practices and the OHRQoL between those who had the chance to attend the SOHP services during their primary school years and those who did not. Therefore, the objective of this study was to evaluate the effects of the SOHP exposure during the primary school years on the current $\mathrm{OH}$ knowledge and practices and OHRQoL of Kuwait University students.

\section{Subjects and Methods}

\section{Study Population}

This is a cross-sectional study among students attending Kuwait University, using a self-administered questionnaire to assess $\mathrm{OH}$ knowledge and practices and OHRQoL. The participants were recruited at the Kuwait University Colleges of Social Sciences, Women, Law, Allied Health Science, Pharmacy, Engineering and Petroleum, and Science. Postgraduate, medical and dental students were excluded because these students were expected to have better $\mathrm{OH}$ knowledge than those from the other schools and colleges. The study protocol was approved by the Joint Committee for the Protection of Human Subjects in Research, Kuwait, was in full accordance with the Declaration of Helsinki and was presented following the STROBE guidelines.

A representative sample of 300 participants was calculated based on a sampling error of 0.05 , using a significance level of 0.1 , a proportion of 0.5 and assuming a $90 \%$ response rate. The students were randomly selected, and written informed consents were obtained. The questionnaires were distributed in classrooms, student unions and cafeterias of the various schools and collected on the spot until the target total number of questionnaires was achieved. Being a university student was the only inclusion criterion. Completion of the questionnaire took about 7-10 min. The questionnaires were assessed for completeness on-site by the team, and the participants were asked to add any missing or incomplete information.

\section{Study Survey}

The questionnaire was developed using previous literature on $\mathrm{OH}$ knowledge and practices $[19,20]$ and self-assessed OHRQoL [19]. The questionnaire included mostly closed-ended questions along with a few open-ended ones. The survey consisted of the 5 sections listed below.

- Demographics: the demographics section had questions about age, gender, marital status, nationality, mother's education level, father's education level, student's field of study, name of primary school, whether the participant's primary school had an $\mathrm{OH}$ program and whether the school had a dental clinic.

- OH knowledge: the $\mathrm{OH}$ knowledge section consisted of 3 openended questions: list 4 dental diseases? Do you know what dental plaque is? (If you do, please define dental plaque.) What are the benefits of fluoridated toothpaste? Also, 6 closed-ended questions about sugar and caries, bacteria and caries, soft drinks and caries, soft drinks and osteoporosis, and the relationship between gum disease and heart problems were asked.

- $\mathrm{OH}$ practices: oral hygiene practices included 6 questions on toothbrushing frequency, use of fluoridated toothpaste, last dental visit and the purpose of that visit.

- Health self-evaluation: this section included a question about whether the participant believes that he or she has a dental disease and 2 questions about how the participant assesses his or her oral and general health, with possible responses being 'very poor', 'poor', 'good', 'very good' and 'excellent'.

- OHRQoL: the OHRQoL part was composed of 3 domains of physical, social and psychological impairments. The responses were scored on a scale from 1 to 5 for each item, with 1 meaning 'all of the time' and 5 meaning 'none of the time'.

\section{Data Analysis}

Data were coded and entered using Epi Info (version 6.0) and were managed and analyzed using the SPSS 21.0 software (IBM Corp., Armonk, N.Y., USA). For the purpose of analysis, the participants were divided into 2 groups: previous SOHP and nonSOHP attendees. Frequencies were used for the description of demographics, health self-evaluation, $\mathrm{OH}$ knowledge and practices 
Table 1. Participants' demographics and SOHP attendance

\begin{tabular}{|c|c|c|c|c|}
\hline Variables & $\begin{array}{l}\text { SOHP } \\
(\mathrm{n}=189)\end{array}$ & $\begin{array}{l}\text { Non-SOHP } \\
(\mathrm{n}=111)\end{array}$ & Total & $\begin{array}{l}\mathrm{p} \\
\text { value }\end{array}$ \\
\hline \multicolumn{5}{|l|}{ Gender } \\
\hline Female & $165(87.3)$ & $95(85.6)$ & $260(86.7)$ & \multirow[t]{2}{*}{0.673} \\
\hline Male & $24(12.7)$ & $16(14.4)$ & $40(13.3)$ & \\
\hline \multicolumn{5}{|l|}{ Marital status } \\
\hline Married & $20(10.6)$ & $18(16.2)$ & $38(12.7)$ & \multirow[t]{2}{*}{0.157} \\
\hline Single & $169(89.4)$ & $93(83.8)$ & $262(87.3)$ & \\
\hline \multicolumn{5}{|l|}{ Nationality } \\
\hline Kuwaiti & $180(95.2)$ & $102(91.9)$ & $282(94)$ & \multirow[t]{2}{*}{0.239} \\
\hline Non-Kuwaiti & $9(4.8)$ & $9(8.1)$ & $18(6)$ & \\
\hline \multicolumn{5}{|l|}{ Type of primary school } \\
\hline Private & $24(12.7)$ & $33(29.7)$ & $57(19)$ & \multirow[t]{2}{*}{$<0.001$} \\
\hline Public & $165(87.3)$ & $78(70.3)$ & $243(81)$ & \\
\hline \multicolumn{5}{|l|}{ Mother's education } \\
\hline High school or less & $63(33.3)$ & $27(24.3)$ & $90(30)$ & \multirow[t]{2}{*}{0.100} \\
\hline College or more & $126(66.7)$ & $84(75.7)$ & $210(70)$ & \\
\hline \multicolumn{5}{|l|}{ Father's education } \\
\hline High school or less & $51(27.0)$ & $27(34.3)$ & $78(26)$ & \multirow[t]{2}{*}{0.612} \\
\hline College or more & $138(73.0)$ & $84(75.7)$ & $222(74)$ & \\
\hline
\end{tabular}

Values represent numbers (\%). The p values were evaluated by $\chi^{2}$ analysis.

and OHRQoL. For OH knowledge and OHRQoL, the scores were calculated for the individual questions. Higher scores reflected better $\mathrm{OH}$ knowledge and/or OHRQoL. Data normality was tested by the Shapiro-Wilk test, and the t test was applied for the statistical evaluation of the means between SOHP and non-SOHP subjects. The associations between SOHP attendance and $\mathrm{OH}$ knowledge, $\mathrm{OH}$ practices and OHRQoL were evaluated by $\chi^{2}$ analysis, and Mantel-Haenszel odds ratios (ORs) were calculated for significant factors.

\section{Results}

\section{Demographics}

The target of 300 fully completed questionnaires was reached. The basic demographics according to SOHP attendance are given in table 1 . A total of $189(63 \%)$ participants were part of the SOHP during their primary school years, while 111 (32\%) did not participate. The mean age of the respondents was $19.6 \pm 1.6$ years (range: 17.6-24.3), of whom 260 (86.7\%) were females and 40 (13.3\%) males (table 1). 262 (87.3\%) respondents were single, and 38 (12.7\%) were married. A total of 210 (70\%) of the study population reported that their mother had a college education, while 222 (74\%) stated that their father had a college education or higher. Of the 300 participants, $243(81 \%)$ studied in public schools, while the remaining
$57(19 \%)$ studied in private schools. 135 (45\%) students were in nonscientific colleges (College of Social Sciences, College of Women, and College of Law), 33 (11\%) were in health-related colleges (College of Allied Health Science, College of Pharmacy), and 132 (44\%) were in scientific colleges (College of Engineering and Petroleum, College of Science). The type of primary school was the only demographic variable significantly associated with SOHP and non-SOHP attendance $(\mathrm{p}<0.001)$. Children in public schools were 3 times as likely to be enrolled in the SOHP $(\mathrm{OR}=2.91,95 \% \mathrm{CI}=1.61-5.25)$ than in private schools.

\section{$\mathrm{OH}$ Knowledge}

The detailed $\mathrm{OH}$ knowledge responses of the participants are shown in table 2 . The mean $\mathrm{OH}$ knowledge score was $10.8 \pm 1.3$ points (range: $0-14$ ). A total of 227 (75\%) participants listed caries prevention as the function of fluoride in toothpaste. Of the 300 participants, 261 (87\%) were aware that sugar causes caries, $216(72 \%)$ that bacteria are not the only cause of caries and 213 (71\%) that gum diseases are related to heart problems, 136 $(45.3 \%)$ that fluoride prevents dental caries in children, $181(60.4 \%)$ that soft drinks cause caries, 104 (36.6\%) that soft drinks cause osteoporosis and 77 (25.7\%) that parents can transmit bacteria to their children.

The association between $\mathrm{OH}$ and SOHP attendance is given in table 3. Regarding the overall knowledge scores, no significant differences were found between the SOHP and the non-SOHP participants $(\mathrm{p}=0.6)$, with means of $10.8 \pm 1.3$ and $10.9 \pm 1.4$, respectively. None of the knowledge components of the study were significantly associated with SOHP attendance except the relationship between gum problems and heart diseases (table 3). SOHP attendees were twice as likely to be aware that gum problems were related to heart diseases than the non-SOHP attendees $(\mathrm{OR}=2,95 \% \mathrm{CI}=1.15-3.48)$.

\section{Oral Hygiene Practices}

Of the 300 participants, $219(73 \%)$ had visited the dentist within 1 year, and $60(27.4 \%)$ of them had gone for a dental checkup (table 2); 290 (96.7\%) brushed their teeth at least once a day using fluoridated toothpaste. The participants' $\mathrm{OH}$ practices are also shown in table 2. None of the studied $\mathrm{OH}$ practices were significantly associated with SOHP attendance $(\mathrm{p}>0.05)$ (table 3$)$.

\section{Health Self-Evaluation}

Of the 300 participants, 81 (27\%) reported that they had dental diseases (table 2). However, 270 (90\%) evalu- 
Table 2. Participants' health self-evaluation, $\mathrm{OH}$ practices and $\mathrm{OH}$ knowledge

\section{Health self-evaluation}

Do you think you have dental diseases?

Yes

No

Don't know

How do you evaluate your $\mathrm{OH}$ ?

Very poor

Poor

Good

Very good

Excellent

How do you evaluate your general health?

Very poor

Poor

Good

Very good

Excellent

\section{$\mathrm{OH}$ practices}

When was the last time you visited a dentist?

1 year ago

2 years ago

$>2$ years ago

$81(27.0)$

$144(48.0)$

$75(25.0)$

$9(3.0)$

$21(7.0)$

183 (61.0)

$69(23.0)$

$18(6.0)$

$3(1.0)$

$15(5.0)$

$165(55.0)$

87 (29.0)

$30(10.0)$

What was the reason for your visit?

Pain (emergency)

Examination

Need for a filling

Tooth removal

Special treatment: RCT, crowns, braces

Do you brush your teeth daily?

$$
\begin{array}{lc}
\text { Yes } & 284(94.6) \\
\text { No } & 16(5.4)
\end{array}
$$

$219(73.0)$

$26(8.7)$

55 (18.3)

$92(30.7)$

$60(20.0)$

$42(14.0)$

25 (8.3)

$81(27.0)$

How many times do you brush your teeth a day?

$<1 /$ day

$1 /$ day

$2 /$ day

$\geq 3$ /day

$10(3.0)$

$46(15.3)$

$169(56.7)$

75 (25.0)

Does your toothpaste contain fluoride?

Yes

$234(78.0)$

$25(8.3)$

$41(13.7)$

Don't know

How much toothpaste do you apply on the brush?

Less than half of the brush

$28(9.3)$

Half of the brush

$80(26.7)$

$49(16.3)$

$143(47.7)$

\section{OH knowledge}

Fluoride is added to the toothpaste for ...

Pleasant taste

$31(10.3)$

Soft feeling

Preventing caries

$37(12.3)$

$228(76.0)$

$4(1.3)$

What oral/dental diseases do you know? Please list

$\begin{array}{lr}\text { None } & 180(60.0) \\ 1 & 67(22.3) \\ 2 & 45(15.0) \\ 3 & 7(2.3) \\ 4 & 1(0.3)\end{array}$

Do you know what dental plaque is?

Yes

$60(20)$

No

$240(80)$

If yes, define

Sugar is a cause of tooth decay

Yes

$261(87.0)$

$23(7.7)$

$16(5.3)$

Don't know

$216(72.0)$

$30(13.3)$

$42(14.0)$

Don't know

$213(71.0)$

$87(29.0)$

No

Don't know

$136(45.3)$

Yes

$46(15.3)$

Don't know

$118(39.4)$

Soft drinks cause tooth decay

Yes

$181(60.4)$

No

$39(13.0)$

Don't know

$80(26.6)$

Soft drinks cause osteoporosis

Yes

$104(34.6)$

No

$33(11.0)$

Don't know

$163(54.4)$

The father/mother do not transmit bacteria to their children

Yes

$77(25.7)$

No

$98(32.6)$

Don't know

Values represent numbers (\%). RCT $=$ Root canal treatment.

1 Total $\mathrm{n}$ is $<300$ due to missing data.

ated their $\mathrm{OH}$ and general health as good, very good or excellent. The participants' self-evaluation of their oral and dental health is summarized in table 2 .

The $\mathrm{OH}$ self-evaluation was significantly associated with SOHP attendance $(\mathrm{p}=0.008)($ table 3$)$. The SOHP attendees were 3 times as likely to describe their $\mathrm{OH}$ status as good/very good/excellent $(\mathrm{OR}=2.85,95 \%$ $\mathrm{CI}=1.31-6.18)$. The participants' health self-evaluations according to SOHP attendance are summarized in table 3 . 
Table 3. Associations between $\mathrm{OH}$ knowledge, $\mathrm{OH}$ practices and health self-evaluation and SOHP attendance

\begin{tabular}{|c|c|c|c|}
\hline & $\begin{array}{l}\text { SOHP } \\
(\mathrm{n}=189)\end{array}$ & $\begin{array}{l}\text { Non-SOHP } \\
(\mathrm{n}=111)\end{array}$ & $\mathrm{p}$ value \\
\hline \multicolumn{4}{|l|}{ OH knowledge } \\
\hline \multicolumn{4}{|c|}{ Fluoride is added to the toothpaste for. } \\
\hline Caries prevention & $147(77.8)$ & $81(73.0)$ & \multirow[t]{2}{*}{0.347} \\
\hline Price/taste/softener/other & $42(22.2)$ & $30(27.0)$ & \\
\hline \multicolumn{4}{|l|}{ Sugar is a cause of tooth decay } \\
\hline No & $27(14.3)$ & $12(10.8)$ & \multirow[t]{2}{*}{0.388} \\
\hline Yes & $162(85.7)$ & $99(89.2)$ & \\
\hline \multicolumn{4}{|c|}{ Bacteria are not the only cause of dental caries } \\
\hline No & $54(28.6)$ & $30(27.0)$ & \multirow[t]{2}{*}{0.774} \\
\hline Yes & $135(71.4)$ & $81(73.0)$ & \\
\hline \multicolumn{4}{|c|}{ Gum problems are related to heart disease } \\
\hline No & $33(17.5)$ & $33(29.7)$ & \multirow[t]{2}{*}{0.013} \\
\hline Yes & $156(82.5)$ & $78(70.3)$ & \\
\hline \multicolumn{4}{|c|}{ Fluoride toothpaste prevents tooth decay in babies } \\
\hline No & $99(52.4)$ & $66(59.5)$ & \multirow[t]{2}{*}{0.234} \\
\hline Yes & $90(47.6)$ & $45(40.5)$ & \\
\hline \multicolumn{4}{|l|}{ Soft drinks cause tooth decay } \\
\hline No & $75(39.7)$ & $45(40.5)$ & \multirow[t]{2}{*}{0.884} \\
\hline Yes & $114(60.3)$ & $66(59.5)$ & \\
\hline \multicolumn{4}{|l|}{ Soft drinks cause osteoporosis } \\
\hline No & $123(65.1)$ & $75(67.6)$ & \multirow[t]{2}{*}{0.584} \\
\hline Yes & $66(34.9)$ & $36(32.4)$ & \\
\hline \multicolumn{4}{|c|}{ The father/mother do not transmit bacteria to their children } \\
\hline No & $135(71.4)$ & $84(75.7)$ & \multirow[t]{2}{*}{0.424} \\
\hline Yes & $54(28.6)$ & $27(24.3)$ & \\
\hline \multicolumn{4}{|l|}{ OH Practices } \\
\hline \multicolumn{4}{|c|}{ When was the last time you visited a dentist? } \\
\hline 1 year ago & $135(71.4)$ & $84(75.7)$ & \multirow[t]{2}{*}{0.423} \\
\hline$\geq 2$ years ago & $54(28.6)$ & $27(24.3)$ & \\
\hline What was the reason for your vis & & & \\
\hline Pain (emergency) & $54(28.6)$ & $39(35.1)$ & 0.235 \\
\hline Other dental procedures & $135(71.4)$ & $72(64.9)$ & \\
\hline Do you brush your teeth daily? & & & \\
\hline No & $12(6.3)$ & $6(5.4)$ & 0.740 \\
\hline Yes & $177(93.7)$ & $105(94.6)$ & \\
\hline How many times do you brush y & teeth a day? & & \\
\hline$<2 /$ day & $39(20.6)$ & $15(13.5)$ & 0.121 \\
\hline$\geq 2 /$ day & $150(79.4)$ & $96(86.5)$ & \\
\hline Does your toothpaste contain flu & & & \\
\hline No & $24(12.7)$ & $16(14.4)$ & 0.673 \\
\hline Yes & $165(87.3)$ & $95(85.6)$ & \\
\hline How much toothpaste do you ap & on the brush? & & \\
\hline Half of the brush or less & $69(36.5)$ & $36(32.4)$ & 0.475 \\
\hline More than half of the brush & $120(63.5)$ & $75(67.6)$ & \\
\hline Health self-evaluation & & & \\
\hline Do you think you have dental di & & & \\
\hline No & $123(65.1)$ & $71(64.0)$ & 0.845 \\
\hline Yes & $66(34.9)$ & $40(36.0)$ & \\
\hline How do you evaluate your $\mathrm{OH}$ ? & & & \\
\hline Very poor/poor & $12(6.3)$ & $18(16.2)$ & 0.008 \\
\hline Good/very good/excellent & $177(93.7)$ & $93(83.8)$ & \\
\hline How you evaluate your general $h$ & & & \\
\hline Very poor/poor & $9(4.8)$ & $9(8.1)$ & 0.239 \\
\hline Good/very good/excellent & $180(95.2)$ & $102(91.9)$ & \\
\hline
\end{tabular}

Values represent numbers (\%). $\mathrm{p}$ values were evaluated by $\chi^{2}$ analysis.

\section{Oral Health-Related Quality of Life}

The participants' OHRQoL responses are shown in table 4 . The mean OHRQoL score was $12 \pm 3$ points (range: 1-15). The number of participants who never faced any teeth and/or gum problems that affected their daily activities during the 3 months before the study was 151 (50.3\%), and 150 (50\%) and 162 (54\%) participants were not affected by such problems in their social life or selfesteem, respectively (table 4).

The participants' OHRQoL according to SOHP attendance is summarized in table 4 . There were no significant differences in the mean OHRQoL between those who went to the SOHP and those who did not $(11.8 \pm 3.2$ and $12.6 \pm 2.8$, respectively; $\mathrm{p}=0.3$ ). Being part of the SOHP was significantly associated with the impact of dental issues on their daily activity $(\mathrm{p}<0.001)$. Non-SOHP attendees were twice as likely to have their daily activities affected by dental health issues compared to the SOHP attendees $(\mathrm{OR}=2.28,95 \% \mathrm{CI}=1.41-3.68)$.

\section{Discussion}

The present study showed that these Kuwait University students had a good level of $\mathrm{OH}$ awareness, an adequate level of practice and good OHRQoL. These findings are similar to previous studies on Kuwaiti adults [20,21]. Most of the respondents were female, since females are the predominant gender at Kuwait University, and single, since the participants were mainly young (mean age $19 \pm$ 1.6 years) and studied in public schools $[12,14]$ as previously reported [20].

The $90 \%$ good-to-excellent self-evaluation of $\mathrm{OH}$ status with acceptable dental attendance rate was $>60 \%$ according to previous reports from university students [20, 21] at the male Health Sciences Colleges [21] and 43\% in the Kuwait University Health Sciences Centre students [20]. These results were also higher than the 39\% found in the national health survey done 20 years ago [22]. However, the $33.3 \%$ rate of emergency and pain management, in this study, was much lower than the reported $70 \%$ among Health Sciences Centre students reported previously [20]. Although this low percentage of emergency visits could indicate some improvement in the $\mathrm{OH}$ status of these university students, the dental attendance for checkup/preventive reasons was very low. Equally important in our study, the dental examination as a reason for their visit was lower than reported by Kassak et al. [19] in Lebanon and less than half of the attendance rate among Italian university students [23]. A possible expla- 
nation could be that routine dental checkups were not common in Kuwait or regional countries [19]. Hence, there is a clear need to encourage these university students to make routine dental checkup visits, which is normally recommended as part of good $\mathrm{OH}$ care [3].

The $81.8 \%$ report of brushing $\geq 2$ /day in the present study was a substantial improvement over the previously reported $43 \%$ for male students at the Health Sciences Colleges in Kuwait [21] and also higher than the 65\% among students in Lebanon [19] but lower than the 92\% in Italian students [23]. These differences could be due to the general changes in $\mathrm{OH}$ knowledge during the last decade [24]. The $86.6 \%$ use of fluoridated toothpaste was similar to the previous report by Al-Ansari et al. [21] and that of the Lebanese study by Kassak et al. [19]. Although some improvements have been found in $\mathrm{OH}$ practices in Kuwait, more health promotion campaigns are needed for this population to achieve optimal $\mathrm{OH}$, and the university setting can be an ideal environment for such initiatives [24].

Both our study and that of Al-Ansari et al. [21] showed a good level of awareness about the role of sugar and bacteria in the development of tooth decay and of fluoridated toothpaste in the prevention of the disease. A lack of knowledge in some $\mathrm{OH}$ aspects was also found in both studies, such as the relationship between soft drinks and tooth decay and the fact that parents/caregivers can transmit their oral bacteria to their child. The majority of the respondents in our study were aware about the relationship between periodontal and heart diseases compared to a lower proportion in the previous report for the male students at the Health Sciences Colleges [21]. It seems that such deficiencies in $\mathrm{OH}$ knowledge have not been targeted in $\mathrm{OH}$ education and promotion since the study by Al-Ansari et al. [21] 12 years ago. Surprisingly, no significant differences in $\mathrm{OH}$ knowledge were seen between the SOHP attendees and the non-SOHP attendees except for the relationship between gum problems and heart disease. A possible explanation could be that other sources of knowledge than the SOHP contributed to the existing knowledge. This knowledge may have been acquired during the primary school years or after graduating high school, and the sources could be parents, a family dentist in private practice or activities done by agencies other than the SOHP.

The OHRQoL of the studied students was relatively higher than that of a previous report of university students in Tanzania [25] as almost 50\% of the students reported that their $\mathrm{OH}$ status never interrupted their lives, and $<5 \%$ were severely affected, compared to Tanzanian
Table 4. Participants' OHRQoL responses and their associations with SOHP attendance and nonattendance

\begin{tabular}{|c|c|c|}
\hline $\begin{array}{l}\text { How often have problems with } \\
\text { your teeth or gums... }\end{array}$ & $\mathrm{n}(\%)$ & $\mathrm{p}$ value \\
\hline \multicolumn{3}{|l|}{$\begin{array}{l}\text { During the past } 3 \text { months } \\
\text { affected your daily activities? }\end{array}$} \\
\hline All of the time & $13(4.3)$ & \\
\hline Most of the time & $20(6.7)$ & \\
\hline Some of the time & $53(17.7)$ & \\
\hline A little of the time & $63(21)$ & \\
\hline None of the time & $151(50.3)$ & \\
\hline \multicolumn{3}{|l|}{ affected your social activities? } \\
\hline All of the time & $9(3)$ & \\
\hline Most of the time & $29(9.7)$ & \\
\hline Some of the time & $49(16.3)$ & \\
\hline A little of the time & $63(21)$ & \\
\hline None of the time & $150(50)$ & \\
\hline \multicolumn{3}{|l|}{ caused avoidance of conversations? } \\
\hline All of the time & $14(4.7)$ & \\
\hline Most of the time & $24(8)$ & \\
\hline Some of the time & $49(16.3)$ & \\
\hline A little of the time & $51(17)$ & \\
\hline None of the time & $162(54)$ & \\
\hline \multicolumn{2}{|l|}{ SOHP } & $<0.001$ \\
\hline No & $108(57.1)$ & \\
\hline Yes & $81(42.9)$ & \\
\hline \multicolumn{3}{|l|}{ Non-SOHP } \\
\hline No & $41(36.9)$ & \\
\hline Yes & $70(63.1)$ & \\
\hline \multicolumn{3}{|l|}{ SOHP } \\
\hline No & $99(52.4)$ & \\
\hline Yes & $90(47.6)$ & \\
\hline \multicolumn{3}{|l|}{ Non-SOHP } \\
\hline No & $51(45.9)$ & \\
\hline Yes & $60(54.1)$ & \\
\hline $\begin{array}{l}\text { caused avoidance of conversations? } \\
\text { SOHP }\end{array}$ & SOHP & 0.146 \\
\hline No & $93(49.2)$ & \\
\hline Yes & $96(50.8)$ & \\
\hline \multicolumn{3}{|l|}{ Non-SOHP } \\
\hline No & $45(40.5)$ & \\
\hline Yes & $66(59.5)$ & \\
\hline
\end{tabular}

university students where $51 \%$ of the students reported that $\mathrm{OH}$ problems affected their daily activities. This reflects the accessibility of the population to $\mathrm{OH}$ services in government centers or private practice, which is a very positive point. Although no significant difference was found in the overall OHRQoL between the SOHP and non-SOHP attendees, the daily activities of the SOHP at- 
tendees were less likely to be affected compared to those of the non-SOHP attendees due to pain and/or functional limitations. This highlights that the impact of the SOHP may extend beyond childhood to affect the participants' lives in adulthood. Such an assumption is confirmed by the very positive self-perception of the $\mathrm{OH}$ status observed in the SOHP attendees compared to the nonSOHP attendees.

One of the limitations of this study was that the questionnaire was only distributed to those who could read English. For a wider participation, a translation of the questionnaire into Arabic would be helpful. Another limitation was that the survey did not include a question about where the students had got their $\mathrm{OH}$ knowledge, which would have allowed to appropriately evalu- ate the school-based $\mathrm{OH}$ education. Last, there was no clinical examination done to validate the OHRQoL responses.

\section{Conclusion}

The SOHP attendance had an extended positive impact on the participants' OHRQoL, especially regarding their daily activities, with an insignificant effect on $\mathrm{OH}$ knowledge or practices. Future research with a much higher number of participants to assess the $\mathrm{OH}$ status and OHRQoL in the population exposed to a school-based program would give a clearer picture on how the population benefited from these programs in their adult life.

\section{References}

1 Williams DM: The research agenda on oral health inequalities: the IADR-GOHIRA initiative. Med Princ Pract 2014;23(suppl 1):5259.

2 Yewe-Dyer M: The definition of oral health. Br Dent J 1993;174:224-225.

3 Kay E, Locker D: A systematic review of the effectiveness of health promotion aimed at improving oral health. Community Dent Health 1998; 15:132-144.

4 Jokovic A, Locker D, Stephens M, et al: Validity and reliability of a questionnaire for measuring child oral-health-related quality of life. J Dent Res 2002;81:459-463.

5 Kramer PF, Feldens CA, Ferreira SH, et al: Exploring the impact of oral diseases and disorders on quality of life of preschool children. Community Dent Oral Epidemiol 2013;41: 327-335.

6 Krisdapong S, Sheiham A: Which aspects of an oral health-related quality of life measure are mainly associated with global ratings of oral health in children? Community Dent Oral Epidemiol 2014;42:129-138.

7 Palencia L, Espelt A, Cornejo-Ovalle M, et al: Socioeconomic inequalities in the use of dental care services in Europe: what is the role of public coverage? Community Dent Oral Epidemiol 2014;42:97-105.

8 Simons D, Pearson N, Evans P: A pilot of a school-based dental treatment programme for vulnerable children with possible dental neglect: the Back2School programme. $\mathrm{Br}$ Dent J 2013;215:E15.
9 Croucher R, Sohanpal R: Improving access to dental care in East London's ethnic minority groups: community based, qualitative study. Community Dent Health 2006;23:95-100.

10 Liang J, Wu B, Plassman B, et al: Racial disparities in trajectories of dental caries experience. Community Dent Oral Epidemiol 2013; 41:517-525.

11 Blomqvist P, Ojala E, Kettunen T, et al: Community-based oral health promotion practices targeted at children and adolescents in Finland - developing an assessment tool. Community Dent Oral Epidemiol 2014;42: 245-253.

12 Ariga J, Al-Mutawa S, Nazar H: School oral health program in Kuwait. Med Princ Pract 2014;23(suppl 1):43-46.

13 Petersen PE: Strengthening of oral health systems: oral health through primary health care. Med Princ Pract 2014;23(suppl 1):3-9.

14 Honkala S: World Health Organization approaches for surveys of health behaviour among schoolchildren and for health-promoting schools. Med Princ Pract 2014;23 (suppl 1):24-31.

15 Morris RE, Al Za'abi F, Behbehani J, et al: Community based schoolchildren's oral health programmes, Kuwait 1985-1998. Int Dent J 2004;54:241-249.

16 Shyama M, Honkala S, Al-Mutawa SA, et al: Oral health-related quality of life among parents and teachers of disabled schoolchildren in Kuwait. Med Princ Pract 2013;22:285-290.
17 Cooper AM, O’Malley LA, Elison SN, et al: Primary school-based behavioural interventions for preventing caries. Cochrane Database Syst Rev 2013;5:CD009378.

18 Ashkanani F, Al-Sane M: Knowledge, attitudes and practices of caregivers in relation to oral health of preschool children. Med Princ Pract 2013;22:167-172.

19 Kassak KM, Dagher R, Doughan B: Oral hygiene and lifestyle correlates among new undergraduate university students in Lebanon. J Am Coll Health 2001;50:15-20.

20 Al-Hussaini R, Al-Kandari M, Hamadi T, et al: Dental health knowledge, attitudes and behaviour among students at the Kuwait University Health Sciences Centre. Med Princ Pract 2003;12:260-265.

21 Al-Ansari J, Honkala E, Honkala S: Oral health knowledge and behavior among male health sciences college students in Kuwait. BMC Oral Health 2003;3:2.

22 Behbehani JM, Shah NM: Oral health in Kuwait before the Gulf War. Med Princ Pract 2002;11(suppl 1):36-43.

23 Rimondini L, Zolfanelli B, Bernardi F, et al: Self-preventive oral behavior in an Italian university student population. J Clin Periodontol 2001;28:207-211.

24 Franklin White: Primary health care and public health: foundations of universal health systems. Med Princ Pract 2015;24:103-116.

25 Masalu JR, Astrom AN: Social and behavioral correlates of oral quality of life studied among university students in Tanzania. Acta Odontol Scand 2002;60:353-359. 